\title{
Antioxidant and Cytotoxicity Activities of Karamunting (Melastoma malabathricum L.) Fruit Ethanolic Extract and Quercetin
}

\author{
Isnaini Isnaini*, Alfi Yasmina, Hendra Wana Nur’amin
}

\begin{abstract}
Melastoma malabathricum L. is a type of plant naturally grows in Kalimantan that has medicinal properties. Ethanolic extract of M. malabathricum L. flower has quercetin and kaempferol contents that have antioxidant and anticancer activities. But the antioxidant and cytotoxicity activities of M. malabathricum L. fruit ethanolic extract were not known. This study measured the quercetin and kaempferol level in M. malabathricum L. fruit ethanolic extract using HPLC MS/MS, antioxidant activity using DPPH method, and cytotoxicity activity using Brine Shrimp Lethality Test (BSLT) method. Results showed the level of quercetin and kaempferol from M. malabathricum L fruit ethanolic extract are $67.78 \mu \mathrm{g} / \mathrm{g}$ and $43.52 \mu \mathrm{g} / \mathrm{g}$, respectively. Beside, the antioxidant activity with by IC50 was $16.82 \pm 0.24 \mathrm{ppm}$ and $7.38 \pm 0.41 \mathrm{ppm}$. The cytotoxicity activities of M. malabathricum L. fruit ethanolic extract and quercetin are shown by the LC50 of 313.44 ppm (95\%CI 283.97-344.43) and 37.24 ppm, respectively.
\end{abstract}

Keywords: $M$. malabathricum $L$ - quercetin- kaempferol- antioxidant- cytotoxicity

Asian Pac J Cancer Prev, 20 (2), 639-643

\section{Introduction}

Melastoma malabathricum L. is a natural plant found in Kalimantan, which is used for traditional drug treatment. It grows wildly in the area and has not been used optimally. Several pharmacological activities of M. malabathricum have been reported, namely, antibacterial (Sunilson et al., 2008; Choudhury et al., 2011; Isnaini et al., 2011), antidiarrheal (Nur'amin et al., 2010; Sunilson et al., 2009), antioxidant (Susanti et al., 2007; Chalise et. al., 2010), gastroprotective (Al-Bayaty et. al., 2008), wound healing (Simanjuntak, 2008; Sunilson et al., 2008), antinociceptive (Sulaiman et al., 2004; Zakaria et al., 2006), anticoagulant (Manicam et al, 2010), antiinflammatory (Mazura et al, 2007; Zakaria et al., 2006), antiviral (Nazlina et al., 2008), and anticancer activities (Susanti et al., 2007; Nazlina et al., 2008).

Parts of the plant that can be used for treatment include the flower and the fruit of M. malabathricum L. Its flower is known to contain quercetin and kaempferol (Isnaini et al., 2018). Quercetin and kaempferol are natural polyphenols that have multiple antioxidant properties that may eliminate ROS through free radical scavenging, metal ion chelation, pro-oxidant enzyme inhibition, antioxidant activation, and enzyme detoxification (Amic and Lucic, 2010). Both compounds can react directly with oxidants and also can induce endogenous antioxidants, such as MnSOD. Quercetin and kaempferol are known to be able to cleave Nrf2 and keap 1, so that Nrf2 is activated and may induce MnSOD (Kimura et al., 2009). Quercetin induces MnSOD in the hepatoma cell line (Amic and Lucic, 2010). Kaempferol induces MnSOD and CAT proteins in human non-small cell lung carcinoma cell line (H460) (Leung et al., 2007).

Quercetin and kaempferol also have anticancer activity. Quercetin effect as anticancer depends on the concentration. Quercetin with the concentration of 1-20 $\mu \mathrm{M}$ has an antiproliferative effect, but in the concentration of $50-200 \mu \mathrm{M}$ has proapoptotic effect by decreasing total viable cells through increased cell apoptosis (Jaganathan and Mandal, 2009). Kaempferol increases cell growth at low concentration (1-10 $\mu \mathrm{M})$ by being estrogen receptor agonist and increasing DNA synthesis. However, kaempferol inhibits DNA synthesis cell growth of MCF-7 cell line at the concentration of 20-90 $\mu \mathrm{M}$ (Wang and Kurzer, 1997). Quercetin causes an increase in phosphatase and tensin homolog (PTEN) and p27, and a decrease in Akt, so that it inhibits growth and causes apoptosis (Kok et al., 2008). Quercetin and kaempferol are known to impair cell cycle at G1/S and G2/M checkpoints (Chahar et al., 2011).

M. malabathricum L. fruit is assumed to contain

Department of Pharmacology and Therapeutics, Faculty of Medicine, Lambung Mangkurat University, South Kalimantan, Indonesia.*For Correspondence: isna_yusuf@yahoo.co.id 
quercetin and kaempferol, as in M. malabathricum L. flower. Until recently, quercetin and kaempferol contents in M. malabathricum L. fruit antioxidant and cytotoxicity effect of $M$. malabathricum L. fruit extract were not known. This study aimed to analyze the antioxidant and cytotoxicity effect of Melastoma malabathricum L. fruit extract.

\section{Materials and Methods}

\section{Collection of M. malabathricum L. fruit samples}

This study used M. malabathricum L. fruit. The fruits were collected in the morning before 10.00 AM from Gunung Kupang area, Banjarbaru, South Kalimantan (3028'39.02" S and 114051'18.69" E). This plaint was identified in the Laboratory of Basic Sciences, Lambung Mangkurat University, Banjarbaru, South Kalimantan, Indonesia.

\section{Extraction of M. malabathricum L. fruit}

M. malabathricum L. fruit was extracted using the maceration method. Pulverized M. malabathricum L. fruit was soaked in ethanol 96\% solvent for 24 hours, and occasionally stirred. Extraction was conducted until the solvent was colorless. The extract was obtained by evaporation using rotary evaporator until thick extract was obtained. It was freeze dried to acquire dry powder.

HPLC analysis of quercetin and kaempferol contents in M. malabathricum L. fruit

Quercetin and kaempferol contents were. analyzed with HPLC-MS/MS. The columns used were from Hypersil Gold specification (50 mm x $2.1 \mathrm{~mm}$ x 1.9 $\mu \mathrm{m}$ ). UHPLC (ACCELLA type 1,250 from Thermo Scientific) consists of vacuum degasser, quaternary pump, thermostatic autosampler, that were controlled with a personal computer using X-Calibur 2.1 program. Mobile-phase A consisted of $0.1 \%$ formic acid in aquabidest, and phase B consisted of $0.1 \%$ formic acid in acetonitrile. A linear gradient with the rate of $300 \mu \mathrm{L} /$ min with mobile phase management as follows: 0-0.6 minutes: $15 \%$ B, 2-3.5 minutes $100 \% \mathrm{~B}$, and 4.5 minutes $15 \% \mathrm{~B}$. Injected volume in LC was $2 \mu \mathrm{L}$. The column was maintained at $30^{\circ} \mathrm{C}$, and autosampler compartment was maintained for $10^{\circ} \mathrm{C}$. Standard calibration for kaempferol with precursor ion $285 \mathrm{~m} / \mathrm{z}$ produced transitional ions 239 , 229, $255 \mathrm{mz}$. Standardization of quercetin precursor ion was $301 \mathrm{~m} / \mathrm{z}$ produced transitional ions $170,245,272 \mathrm{~m} / \mathrm{z}$.

Determination of quantity with the Selected Reaction Monitoring (SRM) method was controlled at 301>179 $\mathrm{m} / \mathrm{z}$ for quercetin and at $285>229 \mathrm{~m} / \mathrm{z}$ for kaempferol. Ionization condition of ESI was as follows: spray pressure $3 \mathrm{kV}$, evaporation temperature $270^{\circ} \mathrm{C}$, capillary temperature $300^{\circ} \mathrm{C}$, nitrogen as sheath gas pressure $40 \mathrm{psi}$, and Aux gas pressure 10 psi with Argon gas.

\section{Antioxidant activity}

The extract was made into several concentration in ethanol at several concentrations (5-25 ppm) for $1 \mathrm{ml}$, and then $3 \mathrm{ml} \mathrm{DPPH} 40 \mathrm{ppm}$ in ethanol was added. As the control, $1 \mathrm{ml}$ ethanol was added with $3 \mathrm{ml}$ DPPH 40 ppm. They were left in a dark room for 30 minutes, then the absorbance was measured at $\lambda 517 \mathrm{~nm}$.

$$
\text { Activity }=\left(\frac{\text { A for blank }-\mathrm{A} \text { for sample })}{\mathrm{A} \text { for blank }} \times 100 \%\right.
$$

Antioxidant activity (by capturing DPPH radicals) data for ethanolic extract of M. malabathricum L. fruit and the pure quercetin were then analyzed and the IC50 values were estimated with probit analysis with Vitamine $\mathrm{C}$ as the comparator.

\section{Cytotoxicity test}

One of the methods to find out anticancer activity is by conducting cytotoxicity test in brine shrimp, usually called Brine Shrimp Lethality Test (BSLT). Brine shrimp embryos were incubated using artificial sea water with $35 \%$ salinity. The containers were filled with \pm 50 -100 brine shrimp eggs, and then they were left for 48 hours. Ethanolic extract of M. malabathricum L. fruit was diluted with DMSO $0.05 \%$ in $35 \%$ salinity sea water to create the concentrations of $62.5,125,250,500,750$, and 1,000 ppm. A total of $20 \mathrm{ml}$ of each solution was put into each container. Each container containing 10 brine shrimps. The control was sea water with $35 \%$ salinity added with DMSO $0.05 \%$. The containers were left for 24 hours, and then the total numbers of dead and survived brine shrimps were calculated from each container, and probit analysis was used to estimate the LC50.

\section{Results}

Measurement of quercetin and kaempferol in ethanolic extract of M. malabathricum L. fruit

The measurement of quercetin and kaempferol with HPLC showed that the quercetin content of the extract was $67.78 \mu \mathrm{g} / \mathrm{g}$ and the kaempferol content was 43.52 $\mu \mathrm{g} / \mathrm{g}$ (Figure 1 and 2 ). HPLC results showed that quercetin had a higher concentration in the extract compared to kaempferol. In the next steps, ethanolic extract of $M$. malabathricum L. fruit was compared only to quercetin.

Antioxidant and cytotoxic activities of ethanolic extract of M. malabathricum L. fruit and quercetin

Ethanolic extract of M. malabathricum L. fruit has lower antioxidant activity compared to quercetin (IC50 $16.82 \pm 0.24 \mathrm{ppm}$ vs $7.38 \pm 0.41 \mathrm{ppm})$. Cytotoxicity test with BSLT method showed that ethanolic extract of $M$. malabathricum L. fruit had higher LC50 compared to quercetin (313.ppm [95\%CI 283.97-344.43] vs 37.24 ppm

Table 1. Antioxidant and Cytotoxic Activities of M. malabathricum L. and Quercetin

\begin{tabular}{lcc}
\hline Compound & $\begin{array}{c}\text { Antioxidant } \\
\text { activity } \\
\text { IC50 } \pm \text { RPD }\end{array}$ & LC50 $(95 \% \mathrm{CI})$ \\
\hline $\begin{array}{l}\text { M. malabathricum L. } \\
\text { fruit extract }\end{array}$ & $16.82 \pm 0.24 \mathrm{ppm}$ & $313.44 \mathrm{ppm}$ \\
Quercetin & $7.38 \pm 0.41 \mathrm{ppm}$ & $37,24 \mathrm{ppm}$ (n.a.) \\
\hline
\end{tabular}

CI, confidence interval, IC50, 50\% inhibitory concentration; LC50, $50 \%$ lethal concentration; RPD, relative percent difference 


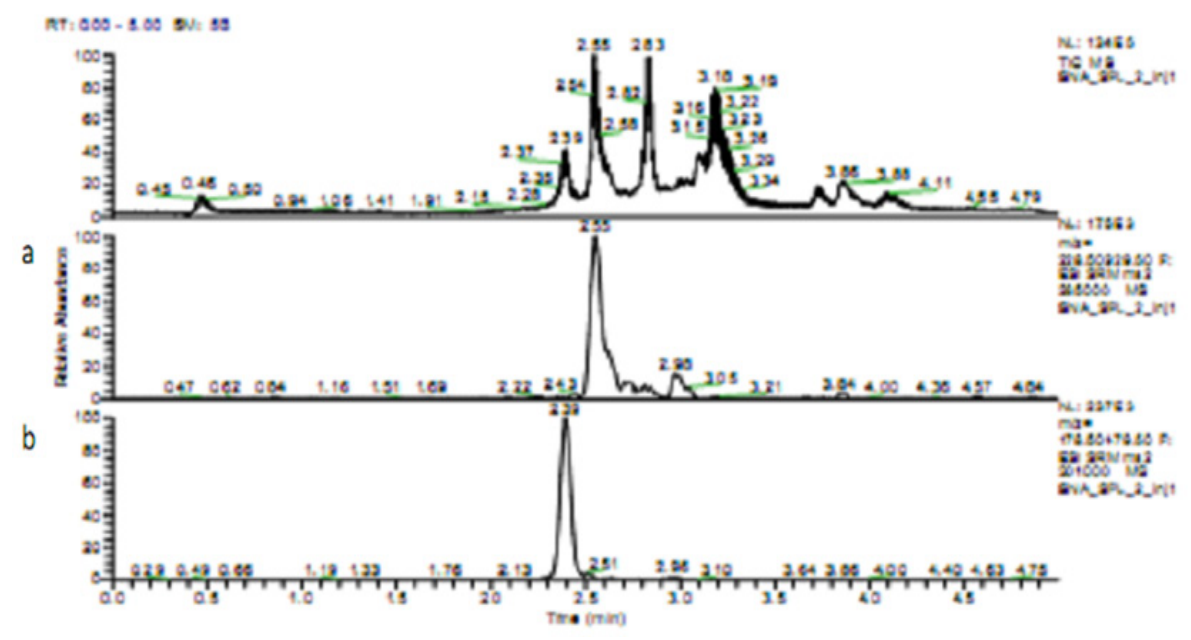

Figure 1. Chromatogram of Kaempferol (a) Quercetin (b) in Ethanolic Extract of M. malabathricum L. Fruit.

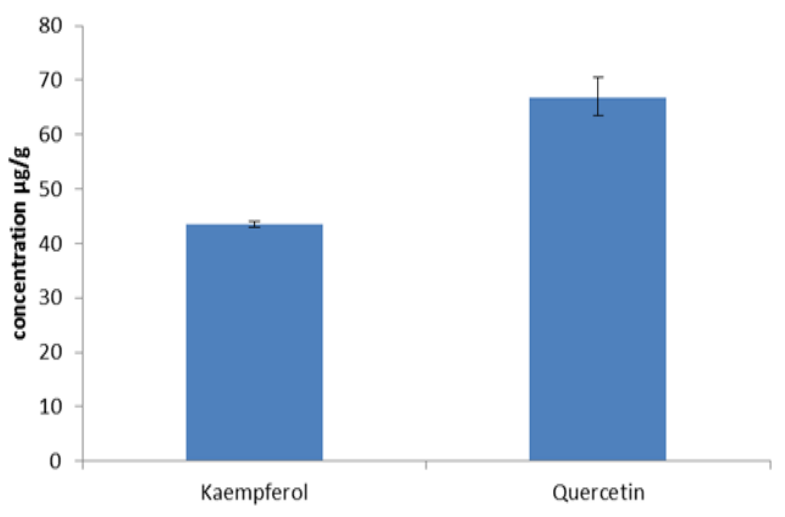

Figure 2. Concentrations of Kaempferol and Quercetin in M. malabathricum L. Fruit Extract Measured with HPLC

[95\%CI n.a.]) (table 1). This means that ethanolic extract of M. malabathricum L. fruit had lower cytotoxicity activity compared to quercetin.

\section{Discussion}

Based on this study, ethanolic extract of $M$. malabathricum L. fruit contains quercetin $(67.78 \mu \mathrm{g} / \mathrm{g})$ and kaempferol $(43.52 \mu \mathrm{g} / \mathrm{g})$. Quercetin content in the fruit is higher than kaempferol, which is different from other studies on quercetin and kaempferol contents in ethanolic extract of $M$. malabathricum L. flower. In various phases of flowers, kaempferol content is higher than quercetin (Isnaini et al., 2018). Quercetin and kaempferol are biosynthesized from narigenin. Narigenin is converted to dihydrokaempferol, and then to kaempferol. Dihydrokaempferol may also be converted to dihydroquercetin, that eventually will be converted to quercetin (Awang et al., 2012). The pathway to produce kaempferol is shorter than that for quercetin; therefore in the flower there is more kaempferol content compared to quercetin (Awang et al., 2012), but in the fruit, it occurs otherwise.

Antioxidant activity of ethanolic extract of $M$. malabathricum L. fruit is weaker than that of quercetin.
Many compounds contained in ethanolic extract of $M$. malabathricum L. fruit affect its antioxidant activity. Aside from quercetin and kaempferol, ethanolic extract of M. malabathricum L. fruit may also contain naringenin (Susanti et al., 2007), anthocyanin (Abdullah et al., 2006) and malvidin-3,4-diglucosyde (Joffry et al., 2012), which also have antioxidant activity (Kharadze et al., 2018; Zaidun et al., 2018). Meanwhile, ethanolic extract of M. malabathricum L. fruit with antioxidant IC50 of $16.82 \mathrm{ppm}$ would have $1.14 \mathrm{ppm}$ quercetin. This IC50 of quercetin in $M$. malabathricum L. fruit extract is smaller than the IC50 of pure quercetin to achieve the same antioxidant activity.

Cytotoxic activity of $M$. malabathricum $\mathrm{L}$. fruit extract was lower than that of quercetin (LC50 313.44 ppm vs $37.24 \mathrm{ppm}$ ). Ethanolic extract of M. malabathricum L. fruit with LC50 of 313.44 ppm would have quercetin content of $67.78 \mu \mathrm{g} / \mathrm{g}$ extract, namely $21.24 \mathrm{ppm}$ quercetin. This LC50 of quercetin in M. malabathricum L. fruit extract is smaller than the LC50 of pure quercetin to achieve the same cytotoxic activity. Naringenin and anthocyanins found in M. melastoma L. fruit also have anticancer activity (Lee et al., 2018). This means that there are other compounds in the fruit extract that have synergistic antioxidant and cytotoxic activities.

Quercetin is the strongest flavonoid to protect the body from reactive oxygen species. Free radicals can impair cellular function and eventually leads to cell death. Quercetin can become direct and indirect antioxidants. Quercetin acts as a direct antioxidant by scavenging free radicals. As an indirect antioxidant, quercetin can induce antioxidant response element (ARE) by activating Nrf2 (Kimura et al., 2009; Miyamoto et al., 2011). Nrf2 is known to be able to induce endogenous antioxidant, namely, CAT, SOD, and GPx (Gibellini et al., 2010). Based on the research by Chang et al., (2009), quercetin can induce MnSOD in human hepatoma cell line HA22T/ VGH at the concentration of $40 \mu \mathrm{M}$ and $60 \mu \mathrm{M}$ after 48 hours exposure.

Ethanolic extract of $M$. malabathricum L. fruit containing quercetin and kaempferol have lower antioxidant and cytotoxic activities compared to pure 
quercetin. These linear antioxidant and cytotoxicity activities may be due to the role of oxidants and antioxidants on cell apoptosis and proliferation. In the study by Isnaini et al., (2018) in breast cancer cell line MCF-7, high oxidants and antioxidants, particularly superoxide radicals, lead to cell proliferation. Therefore the lower antioxidant effect, the lower cytotoxicity from the extract.

Superoxide radical is one of ROS family. ROS can cause increased proliferation, inhibition of proliferation and cell apoptosis depending on its level. The increase in cell numbers is due to an increase in cell proliferation. Cell proliferation occurs through the Akt pathway. ROS may inhibit PTEN resulting in a continuous cycle of the cell path despite mutations or damage to the produced cells (Storz, 2005; Ji, 2007; Kresno, 2011; Prasad et al., 2016). Aside from superoxide radicals, hydrogen peroxide may also cause cell proliferation and apoptosis. Hydrogen peroxide is also a form of non radical ROS that might act as carcinogens. Hydrogen peroxide has biphasic characteristics, because on one side it may induce apoptosis and necrosis, but on the other side it may also cause proliferation, depends on the concentration. Hydrogen peroxide at the concentration of 3-15 $\mu \mathrm{M}$ causes proliferation, at the concertation $0.5-10 \mathrm{mM}$ causes apoptosis, and at the concentration of $5.0-10.0 \mathrm{mM}$ it causes necrosis (Stevenson and Hurst, 2007). Meanwhile, based on the other studies, the concentration of $50 \mathrm{nM}$ has been proven to stimulate cell growth in vitro in various cell pathways, such as in human intestinal cells, rat fibroblasts, and hamster fibroblasts. However, at the concentration of $1 \mu \mathrm{M}-1 \mathrm{mM}$ may cause cytotoxicity in cancer cells (Gupte and Mumper, 2009).

M. malabathricum L. fruit has a small cytotoxicity activity but a large antioxidant activity, so it is not developed as an anticancer drug, but can be developed as an antioxidant drug. Further research is needed regarding the antioxidant mechanism of M. malabathricum L. fruit.

In conclusion, ethanolic extract of $M$. malabathricum L. fruit contains quercetin $(67.78 \mu \mathrm{g} / \mathrm{g})$ and kaempferol $(43.52 \mu \mathrm{g} / \mathrm{g})$. The extract has antioxidant (IC50 16.82 \pm $0.24 \mathrm{ppm}$ ) and cytotoxic activities (LC50 313.44 [283.97344.43] ppm), which might be partly due to its quercetin content.

\section{Conflict of interest}

The authors have no conflict of interest.

\section{Acknowledgements}

We would like to extend our gratitude to the Faculty of Medicine, Lambung Mangkurat University, who has provided the funding for this study.

\section{References}

Al-Bayaty FHMH, Abdulla MA, Noor SM, Ismail S, Ali HM (2008). Gastroprotective effects of Melastoma malabathricum aqueous leaf extract against ethanol-induced gastric ulcer iin rats. Am J Biochem Biotechnol, 4, 438 - 41. Amic D, Lucic B (2010). Reliability of bond dissociation enthalpy calculated by the PM6 method and experimental TEAC values in antiradical QSAR of flavonoids. Bioorg Med Chem, 18, 28-35.

Awang CNC, Abidin KhZ, Ayob Z, Rahman NAA, Samad AA. (2012). Screening for high kaempferol content in different species of Malaysian medicinal plants. J Teknol, 59, 69-73.

Chalise JP, Acharya K, Gurung N, et al (2010). Antioxidant activity and Polyphenol content in edible wild fruits From Nepal. Int J Food Sci Nutr, 61, 425 - 32.

Chahar MK, Sharma N, Dobhal MP, Joshi YC (2011). Flavonoids: A versatile source of anticancer drugs. Pharmacogn Rev, 5, 1-12.

Chang YF, Hsu YC, Hung HF, et al (2009). Quercetin induces oxidative stress and potentiates the apoptotic action of 2-Methoxyestradiol in human hepatoma cells. Nutr Cancer, 61, 735- 45.

Choudhury MD, Nath D, Talukdar A (2011). Antimicrobial activity of M. malabathricum L. J Biol Environ Sci, 7, 76 - 8.

Gibellini L, Pinti M, Nasi M, et al (2010). Interfering with ROS metabolism in cancer cells: The potential role of quercetin. Cancers, 2, 1288-311.

Gupte A, Mumper RJ (2009). Elevated copper and oxidative stress in cancer cells as a target for cancer treatment. Cancer Treat Rev, 35, 32- 46.

Isnaini, Muthmainah N (2011). Antibacterial potential of ethanol extract of karamunting flowers (Melastoma Malabathricum L) in Escherichia Coli, Salmonella Thypi, Streptococcus aureus. Res Rep, Not published.

Isnaini, Permatasari N, Mintaroem K, Widodo MA. (2018). Analysis of quercetin and kaempferol levels in various phase of flowers Melastoma malabathricum L. Int J Plant Biol, 9, 6846.

Isnaini, Permatasari N, Mintaroem K, Prihardina B, Widodo MA (2018). Oxidants-antioxidants profile in the breast cancer cell line MCF-7. Asian Pac J Cancer Prev, 19, 3175 - 8.

Jaganathan SK, Mandal M (2009). Antiproliferative effects of honey and of its polyphenols: A review. J Biomed Biotechnol, 2009.

Abdullah JO, Khairul A, Maziah M, Mohd Y (2006). Flower pigment analysis of Melastoma malabathricum. Afr $J$ Biotechnol, 5, 170 - 4.

Ji LL (2007). Antioxidant signaling in skeletal muscle: a brief review. Exp Gerontol, 42, 582 - 93.

Joffry SM, Yob NJ, Rofiee MS, et al (2012). Ethnomedicinal uses, chemical constituents, and pharmacological properties: a review. J Evid Based Complementary Altern Med, 2012 , 48.

Kharadze M, Japaridze I, Kalandia A, Vanidze M (2018). Anthocyanins and antioxidant activity of red wines made from endemic grape varieties. Ann Agrarian Sci, 16, 181 - 4.

Kimura S, Warabi E, Yanagawa T, et al (2009). Essential role of Nrf2 in keratinocyte protection from UVA by quercetin. Biochem Biophys Res Commun, 387, 109 - 14.

Kok TMD, Breda SGV, Manson MM (2008). Mechanisms of combined action of different chemopreventive dietary compounds. Eur J Nutr, 47, 51 - 9.

Kresno SB (2011). Basic science oncology. second edition. Faculty of Medicine UI. Jakarta, pp 25 - 35.

Lee J, Kim DH, Kim JH (2018). Combined administration of naringenin and hesperetin with optimal ratio maximizes the anti-cancer effect in human pancreatic cancer via down regulation of FAK and p38 signaling pathway. $J$ Phytomedicine, Article in Press. Available November 2018 .

Leung HW, Lin CJ, Hour MJ, et al (2007). Kaempferol induces apoptosis in human lung non-small carcinoma cells accompanied by an induction of antioxidant enzymes. Food 
Chem Toxicol, 45, $2005-13$.

Manicam C, Abdullah JO, Mohd Tohit ER, et al (2010). In vitro anticoagulant activities of M. malabathricum Linn. Aqueous leaf extract: A preliminary novel finding. J Med Plants Res, 4, $1464-72$.

Mazura MP, Susanti D, Rasadah MA (2007). Anti-inflammatory Action of Components from M. malabathricum. J Pharm Biol, 45, $372-5$.

Miyamoto N, Izuma H, Miyamoto R, et al (2011). Quercetin induces the expression of peroxiredoxins 3 and 5 via the Nrf2/NRF1 transcription pathway. Invest Ophthalmol Vis Sci, 52, $1055-63$.

Nazlina I, Norha S, Noor Zarina AW, Ahmad IB (2008). Cytotoxicity and antiviral activity of M. malabathricum extracts. Malays Appl Biol, 37, 53 - 5.

Nur'amin HW, Isnaini, Bakhriansyah M (2010). Potential of Melastoma malabathricum L. fruit Against diarrhea in male mice (Mus musculus) induced by castor oil (Oleum ricini). Res Rep, Not published

Prasad S, Gupta SC, Tyagi AK (2017). Reactive oxygen species (ROS) and cancer: Role of antioxidative Nutraceuticals. Cancer Lett, 387, 95 - 105.

Simanjuntak MR (2008). Ekstraksi Dan Fraksinasi Komponen Ekstrak Daun Tumbuhan Senduduk (M. malabathricum L) Serta Pengujian Efek Sediaan Krim Terhadap Penyembuhan Luka Bakar. Fakultas Farmasi Universitas Sumatera Utara. Medan.

Stevenson DE, Hurst RD (2007). Polyphenolic phytochemicals - just antioxidants or much more?. Cell Mol Life Sci, 64, $2900-16$.

Storz P (2005). Reactive oxygen species in tumor progression. Front Biosci, 10, 1881 - 96.

Sulaiman MR, Somchit MN, Israf DA, Ahmad Z, Moin S (2004). Antinociceptive effect of M. malabathricum ethanolic extract in Mice. Fitoterapia, 75, $667-72$.

Sunilson JAJ, James J, Thomas J, et al (2008). Antibacterial and Wound Healing Activities of M. malabathricum Linn. Afr J Infect Dis, 2, 68 - 73 .

Sunilson JAJ, Anandarajagopal K, Kumari AVAG, Mohan S (2009). Antidiarrhoeal activity of leaves of M. malabathricum Linn. Indian J Pharm Sci, 71, 691 - 5.

Susanti D, Sirat HM, Farediah A (2007). Antioxidant and cytotoxic flavonoids from the flowers of M. malabathricum L. Food Chem, 103, $710-6$.

Wang C, Kurzer MS (1997). Phytoestrogen concentration determines effects on DNA synthesis in human breast cancer cells. Nutr Cancer, 28, 236 - 47.

Zaidun NH, Thent ZC, Latiff AA (2018). Combating oxidative stress disorders with citrus flavonoid. Naringenin Life Sci, 208, 111 - 22

Zakaria ZA, Raden Mohd Nor RNS, Sulaiman MR, et al (2006). Antinociceptive and anti-inflammatory properties of $M$. malabathricum leaves choloform extract in Eksperimental animals. J Pharm Toxicol, 84, 1291-9.

\section{(c) (7) (8)}

This work is licensed under a Creative Commons AttributionNon Commercial 4.0 International License. 